\title{
Effect of dietary NDF levels on nutrient digestion in hindgut of sheep*
}

\author{
X.H. Kong ${ }^{1,2}$, Y.Z. Zhang ${ }^{1}$, X.P. Zhu' ${ }^{1}$, J.S. Guo ${ }^{2}$, R.L. Wang ${ }^{1}$, \\ W. Zhang ${ }^{1}$, C.X. Zhang ${ }^{1}$, C.W. Yue ${ }^{1,2}$ and Z.H. Jia ${ }^{1,3}$ \\ ${ }^{1}$ College of Animal Science and Technology, China Agricultural University \\ Yuanmingyuan West Road 2, Beijing 100094, P. R. China \\ ${ }^{2}$ Department of Animal Science, Hebei North University \\ Zhangjiakou 071000, P.R. China
}

\begin{abstract}
Four 4-month-old wethers fitted with ileal canulas were fed iso-caloric and iso-nitrogenous diets containing different NDF levels (30.0 to $45.0 \%)$ in a $4 \times 4$ Latin square design to evaluate the effects of dietary NDF levels on nutrient digestion in hindgut of sheep. The percent of hindgut digestion of DM, OM, CP, NDF, ADF, hemicellulose and cellulose in total tract digestion was 28.0 to $31.8 \%$, 19.3 to $21.9 \%, 14.1$ to $16.2 \%, 22.3$ to $25.1 \%, 22.0$ to $25.2 \%, 22.7$ to $25.1 \%$ and 18.1 to $21.5 \%$, respectively. Lower (30\%) or higher (45\%) NDF content in diet of sheep depressed fibrous fraction digestion anterior to hindgut, and hindgut complementally increased digestion of fibrous fractions.
\end{abstract}

KEY WORDS: NDF, nutrient, hindgut, digestion, sheep

\section{INTRODUCTION}

The hindgut of ruminant includes caecum, colon and rectum. The caecum and first region of the proximal colon act as a single compartment, which is the main site of fermentative digestion in hindgut. It was indicated that the hindgut made a significant contribution to fermentative digestion in ruminants, particularly when they were fed diets of low nutritive value. Forage to concentrate ratio is one of the main factors on nutrient digestion in ruminants, however, limited studies determined its effect on nutrient digestion in hindgut (Lewis et al., 1985; Siciliano-Jones et

\footnotetext{
* Supported by Chinese National Programs for High Technology and Development, Project No. 2002AA241181

${ }^{3}$ Corresponding author: e-mail: z.h.jia13@cau.edu.cn
} 
al., 1989), and the results were variable. In these trials, the animals were fed ad libitum, thus, had different feed intake, and feed intake could affect digestibility of dietary nutrients. Neutral detergent fibre (NDF) is a main index to reflect forage to concentrate ratio of diet. This study was conducted to determine the effects of NDF levels of diets with iso-caloric and iso-nitrogen on nutrient digestion in hindgut of sheep with same feed intake.

\section{MATERIAL AND METHODS}

\section{Animals and diets}

Four 4-mo-old cross-bred (Small-Tailed Han sheep $\times$ Poll Dorset) wether lambs (BW $23.5 \pm 0.6 \mathrm{~kg}$ ) were used in a $4 \times 4$ Latin square design. Each was fitted with an ileal cannula of $5 \mathrm{~mm}$ internal diameter. The ileal cannula was placed approximately $15 \mathrm{~cm}$ cranial to the ileo-caecal junction. The surgery was completed 3 weeks before the experiment. Animals were housed individually in pens. To ensure full consumption, diets were fed restrictedly and $900 \mathrm{~g}$ (DM basis) feed were fed at 06.00 and 18.00 in two equal allotments. Water was freely available at all times. The ingredients and chemical composition of experimental diets were presented in Table 1. Diets were formulated to be $30,35,40$ and $45 \% \mathrm{NDF}$, respectively, be iso-caloric and iso-nitrogenous and meet the $\mathrm{CP}$ requirements for $50 \mathrm{~g}$ of gain/d (NRC, 1985).

\section{Experimental procedure}

Each experimental period lasted 15 days, with the first 11 days for dietary adaptation and 4 days for sample collection. On days 12-13, faecal samples were collected. Ileal samples were collected on days 14-15. From 06.00 on d 14 to 04.00 on d 15, ileal digesta samples were taken at $2 \mathrm{~h}$ intervals. From 07.00 on d 15 to 05.00 on $\mathrm{d} 16$, ileal digesta samples were taken at $2 \mathrm{~h}$ intervals. Twenty-four ileal samples from each lamb were composited for each period by the mixing of equal portions of each. Feed, faecal and ileal samples were dried at $50^{\circ} \mathrm{C}$ in an air-forced oven.

\section{Chemical analyses}

All samples were analysed for DM, organic matter $(\mathrm{OM})$ and $\mathrm{CP}$ content according to AOAC (1990), for NDF, acid detergent fibre (ADF), hemicellulose (HC) and cellulose (CEL) content according to Van Soest et al. (1991) and Yang (1993). Feed, faecal and ileal samples were analysed for 4M-HCl-insoluble ash (AIA) (Van Keulen and Young, 1977). 
Table 1. Ingredients and chemical composition of experimental diets

\begin{tabular}{|c|c|c|c|c|}
\hline Items & NDF30 & NDF35 & NDF40 & NDF45 \\
\hline \multicolumn{5}{|l|}{ Ingredients, $\%$} \\
\hline Chinese wild rye-grass hay ${ }^{1}$ & 0.0 & 30.0 & 50.0 & 59.0 \\
\hline maize stover ${ }^{1}$ & 37.5 & 16.5 & 0.0 & 0.0 \\
\hline cracked maize & 46.7 & 39.7 & 27.9 & 11.2 \\
\hline wheat bran & 0.0 & 0.0 & 12.0 & 14.7 \\
\hline soyabean meal & 14.7 & 12.7 & 7.0 & 5.0 \\
\hline cotton meal & 0.0 & 0.0 & 2.0 & 5.5 \\
\hline soyabean oil & 0.0 & 0.0 & 0.0 & 3.5 \\
\hline ground limestone & 0.2 & 0.2 & 0.2 & 0.2 \\
\hline $\mathrm{NaCl}$ & 0.6 & 0.6 & 0.6 & 0.6 \\
\hline trace mineral premix ${ }^{2}$ & 0.3 & 0.3 & 0.3 & 0.3 \\
\hline \multicolumn{5}{|l|}{ Chemical composition, \% DM } \\
\hline dry matter & 89.9 & 89.9 & 90.4 & 90.2 \\
\hline organic matter & 94.4 & 93.5 & 92.0 & 91.3 \\
\hline crude protein & 14.0 & 14.0 & 14.0 & 14.3 \\
\hline $\mathrm{Ca}$ & 0.3 & 0.3 & 0.3 & 0.4 \\
\hline total P & 0.3 & 0.3 & 0.3 & 0.4 \\
\hline neutral detergent fibre & 30.0 & 35.0 & 40.0 & 45.0 \\
\hline acid detergent fibre & 16.7 & 21.2 & 23.8 & 27.7 \\
\hline hemicellulose & 14.2 & 14.9 & 16.0 & 17.3 \\
\hline cellulose & 10.9 & 14.5 & 16.8 & 19.6 \\
\hline Metabolizable energy $^{3}, \mathrm{MJ} / \mathrm{kg}$ & 9.1 & 9.1 & 8.9 & 9.0 \\
\hline
\end{tabular}

${ }^{1}$ Chinese wild rye-grass hay and mize stover were coarsely chopped ( $2 \mathrm{~cm}$ length)

${ }^{2}$ containing, mg/kg: Zn 8400, Mn 6000, Fe 4000, Cu 3000, I 260, Co 50, Se 20

${ }^{3}$ values based on NRC (1985)

\section{Calculations and statistical analyses}

AIA was used as an endogenous marker for calculating the apparent digestibilities of major nutrients. According to the percentage values of AIA and nutrients in feed, faecal, and ileal samples, total tract and ileal apparent digestibilities were caculated. Hindgut apparent digestibility was obtained by subtracting ileal apparent digestibility from total tract apparent digestibility.

Data were analysed using ANOVA procedures of SAS (1999), and the means were compared by Duncan-test.

\section{RESULTS AND DISCUSSION}

The dietary NDF levels effected $(\mathrm{P}<0.01)$ the ileal DM digestibility of sheep, with lowest value for sheep fed the diet containing $45 \% \mathrm{NDF}$, and had not effect $(\mathrm{P}>0.05)$ 
on the hindgut digestibility of DM or OM and its percent in total tract digestion, but, with highest value for sheep fed the diet containing 45\% NDF (Table 2).

Dietary NDF levels had not effect $(\mathrm{P}>0.05)$ on $\mathrm{CP}$ digestibility in ileum and hindgut. But, the $\mathrm{CP}$ ileum digestibility of sheep fed the diet containing $45 \%$ NDF was lower than others, and its percent of hindgut digestion in total tract digestion was higher. Lewis et al. (1985) found that the percentage of CP caecum digestion of sheep fed diets of, \%: 60 maize: 40 hay and 80 maize: 20 hay were 21.6 and 22.0 , which accounted for 37.96 and $34.10 \%$ of total tract digestion of $\mathrm{CP}$, respectively. In present experiment, the percent of $\mathrm{CP}$ digestion in hindgut accounted for 14.1 to $16.2 \%$ of the total digestible CP. However, Siciliano-Jones et al. (1989) indicated that CP digested in the large intestine of cow fed diets containing, \%: 20 hay: 80 grain and 80 hay: 20 grain only accounted for 3.2 and $0.3 \%$ of total tract digestion of $\mathrm{CP}$, respectively, which

Table 2. Effect of dietary NDF levels on DM, OM and CP digestion in sheep

\begin{tabular}{|c|c|c|c|c|c|}
\hline \multirow{2}{*}{ Items } & \multicolumn{4}{|c|}{ Diet } & \multirow{2}{*}{ SEM } \\
\hline & NDF30 & NDF35 & NDF40 & NDF45 & \\
\hline \multicolumn{6}{|l|}{ Digestion of dry matter } \\
\hline total tract, $\%$ intake & $72.1^{\mathrm{a}}$ & $71.9^{\mathrm{a}}$ & $71.2^{\mathrm{a}}$ & $69.9^{b}$ & 0.4 \\
\hline ileum, \% intake & $51.9^{\mathrm{aA}}$ & $51.6^{\mathrm{aA}}$ & $50.2^{\mathrm{aAB}}$ & $47.7^{\mathrm{bB}}$ & 0.5 \\
\hline hindgut, $\%$ intake & 20.2 & 20.3 & 21.0 & 22.2 & 0.7 \\
\hline hindgut digestion, $\%$ in total tract & 28.0 & 28.3 & 29.5 & 31.8 & 0.8 \\
\hline \multicolumn{6}{|l|}{ Digestion of organic matter } \\
\hline total tract, $\%$ intake & 73.7 & 73.6 & 72.8 & 72.0 & 0.4 \\
\hline ileum, \% intake & $59.4^{\mathrm{aA}}$ & $59.2^{\mathrm{aA}}$ & $57.6^{\mathrm{bB}}$ & $56.2^{\mathrm{cB}}$ & 0.3 \\
\hline hindgut, \% intake & 14.2 & 14.4 & 15.2 & 15.7 & 0.5 \\
\hline hindgut digestion, $\%$ in total tract & 19.3 & 19.6 & 20.9 & 21.9 & 0.6 \\
\hline \multicolumn{6}{|l|}{ Digestion of crude protein } \\
\hline total tract, $\%$ intake & 72.7 & 72.8 & 73.1 & 72.5 & 1.0 \\
\hline ileum, \% intake & 62.5 & 62.4 & 62.0 & 60.7 & 0.6 \\
\hline hindgut, $\%$ intake & 10.2 & 10.4 & 11.0 & 11.7 & 0.6 \\
\hline hindgut digestion, $\%$ in total tract & 14.1 & 14.3 & 15.1 & 16.2 & 0.7 \\
\hline
\end{tabular}

${ }^{1}$ standard error of the mean; ${ }^{\text {a,b,c }}$ means within a row lacking a common superscript letter indicates significant difference at $\mathrm{P}<0.05$ and ${ }^{\mathrm{A}, \mathrm{B}}$ at $\mathrm{P}<0.01$

may be resulted from incomplete recovery of the indicator (chromic oxide). Hoover (1978) mentioned that ammonia absorption from the hindgut contributed $39 \%$ of the total nonprotein nitrogen absorbed into body fluids, and was probably a major source of nitrogen recycled to the rumen. The ileal NDF and HC digestibility of sheep fed four diets were similar, but the ileal ADF and CEL digestibility of sheep fed 30 and $45 \%$ NDF diets were lower than those of sheep fed 35 and $40 \%$ NDF 
diets (Table 3). The result indicated that lower (30\%) or higher (45\%) NDF in diet decreased fibrous fractions digestion anterior to hindgut. Dietary NDF level did not affect the hindgut NDF, ADF, HC and CEL digestibility of and the percent of hindgut digestion of fibrous fractions in total tract digestion of sheep, but common trend was that corresponding values of 30 and $45 \%$ NDF diets were higher than those of 35 and $40 \%$ NDF diets, and it indicated that digestion of fibrous fractions escaped rumen fermentation then reaching hindgut complementally increased.

Table 3. Effect of dietary NDF levels on fibrous fraction digestion in sheep

\begin{tabular}{|c|c|c|c|c|c|}
\hline \multirow{2}{*}{ Items } & \multicolumn{4}{|c|}{ Diet } & \multirow{2}{*}{ SEM* } \\
\hline & NDF30 & NDF35 & NDF40 & NDF45 & \\
\hline \multicolumn{6}{|l|}{ Digestion of neutral detergent fibre } \\
\hline total tract, $\%$ intake & 51.9 & 52.5 & 52.1 & 51.6 & 0.3 \\
\hline ileum, \% intake & 38.8 & 40.7 & 40.2 & 38.7 & 0.7 \\
\hline hindgut, $\%$ intake & 13.1 & 11.8 & 11.9 & 12.9 & 0.5 \\
\hline hindgut digestion, $\%$ in total tract & 25.1 & 22.3 & 22.9 & 25.1 & 1.1 \\
\hline \multicolumn{6}{|l|}{ Digestion of acid detergent fibre } \\
\hline total tract, $\%$ intake & 50.7 & 51.4 & 50.8 & 49.9 & 0.5 \\
\hline ileum, \% intake & $37.9^{\mathrm{bc}}$ & $40.1^{\mathrm{a}}$ & $39.4^{\mathrm{ab}}$ & $37.4^{\mathrm{c}}$ & 0.5 \\
\hline hindgut, \% intake & 12.8 & 11.3 & 11.4 & 12.5 & 0.5 \\
\hline hindgut digestion, $\%$ in total tract & 25.2 & 22.0 & 22.5 & 25.1 & 1.0 \\
\hline \multicolumn{6}{|l|}{ Digestion of hemicellulose } \\
\hline total tract, $\%$ intake & 53.2 & 54.0 & 54.0 & 54.2 & 0.6 \\
\hline ileum, \% intake & 39.9 & 41.7 & 41.3 & 40.7 & 1.5 \\
\hline hindgut, \% intake & 13.3 & 12.3 & 12.7 & 13.5 & 1.3 \\
\hline hindgut digestion, $\%$ in total tract & 25.0 & 22.7 & 23.6 & 25.1 & 2.4 \\
\hline \multicolumn{6}{|l|}{ Digestion of cellulose } \\
\hline total tract, $\%$ intake & 50.9 & 52.8 & 54.6 & 52.7 & 0.9 \\
\hline ileum, \% intake & $39.9^{\mathrm{D}}$ & $43.3^{\mathrm{B}}$ & $44.2^{\mathrm{A}}$ & $41.6^{\mathrm{C}}$ & 0.6 \\
\hline hindgut, \% intake & 11.0 & 9.5 & 10.4 & 11.1 & 0.5 \\
\hline hindgut digestion, $\%$ in total tract & 21.5 & 18.1 & 19.1 & 21.1 & 0.8 \\
\hline
\end{tabular}

* standard error of the mean; ${ }^{\mathrm{a}, \mathrm{b}, \mathrm{c}}$ means within a row lacking a common superscript letter indicates significant difference at $\mathrm{P}<0.05$ and ${ }^{\mathrm{A}, \mathrm{B}, \mathrm{C}, \mathrm{D}}$ at $\mathrm{P}<0.01$

Lewis et al. (1985) reported that hindgut digestion of NDF, ADF and CEL of sheep fed diets with, \%: 60 maize: 40 hay and 40 maize: 60 hay accounted for 15.9 and $12.9 \%, 29.7$ and $33.6 \%$, and 23.4 and $36.8 \%$ of the total digestible NDF, ADF and CEL, respectively. In present experiment, the percent of hindgut digestion of NDF and ADF in total tract digestion was 22.3 to $25.1 \%$ and 22.0 to $25.2 \%$, respectively. Callison et al. (2001) mentioned that large intestinal NDF digestion of dairy cow accounted for 9.5 to $18.9 \%$ of the total digestible NDF. Siciliano-Jones et al. (1989) 
reported that large intestinal NDF and ADF digestion of sheep accounted for 4.9 to $15.5 \%$ and 5.0 to $14.9 \%$ of the total digestible NDF and ADF, respectively. Possible reasons causing the difference of fibrous fractions digestion in hindgut may include feed sources, forage maturity, concentrate to forage ratio, feed intake, and so on.

Hoover (1978) reviewed that, in ruminants, the hindgut digestion of $\mathrm{HC}$ accounted for 30 to $40 \%$ of the total $\mathrm{HC}$ digested per day, and the hindgut digestion of CEL accounted for 18 to $27 \%$ of the total CEL digested. In present experiment, the percent of hindgut digestion of $\mathrm{HC}$ and CEL in total tract digestion of sheep was 22.7 to $25.1 \%$ and 18.1 to $21.5 \%$, respectively.

\section{CONCLUSIONS}

It is concluded that increasing dietary NDF levels from 30 to $45 \%$ a little increased the percent of hindgut digestion of DM, OM and CP in total tract digestion of sheep, and dietary NDF level had not significant effect on the percent of hindgut digestion of $\mathrm{NDF}, \mathrm{ADF}, \mathrm{HC}$ and CEL in total tract digestion, but corresponding values fed 30 and $45 \%$ NDF diets were higher than those of 35 and $40 \%$ NDF diets. Hindgut digestion has a compensating or equalizing effect on total tract digestibility.

\section{REFERENCES}

AOAC, 1990. Association of Official Analytical Chemists, Official Methods of Analysis. 15th Edition. Washington, DC

Callison S.L., Firkins J.L., Eastridge M.L., Hull B.L., 2001. Site of nutrient digestion by dairy cows fed corn of different particle size or steam-rolled. J. Dairy Sci. 84, 1458-1467

Hoover W.H., 1978. Digestion and absorption in the hindgut of ruminants. J. Anim. Sci. 46, 17891799

Lewis S.M., Dehority B.A., 1985. Microbiology and ration digestibility in the hindgut of the ovine. Appl. Environ. Microbiol. 50, 356-363

NRC, 1985. Nutrient Requirements of Sheep. National Research Council. 6th revised Edition. National Academy Sciences. Washington, DC

SAS, 1999. SAS User's Guide: Statistics (Version 8.01 Ed). SAS Institute Inc. Cary, NC

Siciliano-Jones J., Murphy M.R., 1989. Nutrient digestion in the large intestine as influenced by forage to concentrate ratio and forage physical form. J. Dairy Sci. 72, 471-484

Van Keulen J., Young B.A., 1977. Evaluation of acid insoluble ash as a natural marker in ruminant digestibility studies. J. Anim. Sci. 44, 282-287

Van Soest P.J., Robertson J.B., Lewis B.A., 1991. Symposium: Carbohydrate Methodology, Metabolism and Nutritional Implications in Dairy Cattle. Methods for dietary fiber, neutral detergent fiber, and nonstarch polysaccharides in relation to animal nutrition. J. Dairy Sci. 74, 3583-3597

Yang S., 1993. The Measuring Technology of Feed Analysis and Feed Quality. Beijing Agricultural University Press, Beijing, pp. 58-63 